\title{
Perfect Your Theory Using the Principle of Harmony in Gradation
}

\section{Sigit Haryadi}

\begin{abstract}
For hundreds of years, experts have made mistakes when making the research conclusions and compiling the theory since they have hold to an inaccurate interpretation of the original nature of the measurement data in the system being observed. In detail, so far all methods of parsing and interpreting the nature of a system are based on a one-sided formula, which only sees the "good side" or vice versa only sees the "bad side" of the system being observed, then the results impossible to be accurate.

The principle of Harmony in Gradation bases on a combination of formula that observe the "good side" of the system referred to as "the Harmony" and formula that observe the "bad side" of the system referred to as "the Gradation". Then, the resulting calculation will be able to accurately represent the original nature of the observed data. Thus, by adhering to the principle of Harmony in Gradation, experts will be able to make the accurate research conclusions and theoretical formulations. Finally, this article is equipped with a report of simulation results which proves the validity of the proposed method, online method and discussion for further use of the method.
\end{abstract}

Keywords: data interpretation; nature of data; the Harmony; the Gradation; Harmony in

\section{Gradation}

\section{Citations}

\author{
APA \\ Haryadi, S. (2019, October 25). Perfect Your Theory Using the Principle of Harmony in \\ Gradation. Retrieved from osf.io/preprints/inarxiv/hr9e7
}

MLA 
Haryadi, Sigit. "Perfect Your Theory Using the Principle of Harmony in Gradation." INA-Rxiv, 25 Oct. 2019. Web.

\section{Chicago}

Haryadi, Sigit. 2019. "Perfect Your Theory Using the Principle of Harmony in Gradation." INA-Rxiv. October 25. osf.io/preprints/inarxiv/hr9e7.

\section{Introduction}

A painting or natural landscape that has a combination of shapes and colors look beautiful if there is a harmony of the gradation of the shapes and colors that lie in suitable positions. Also, a musical composition that has a combination of tone and rhythm will sound melodious if there is a harmony of the tonal gradation and the rhythm that lies in the appropriate time sequence. Then, inspired by paintings, natural scenery, and music, we came up with the idea that in order for us to interpret the nature of the measurement data of a system, we should base our analysis using a formula that contains the harmony of gradations that exist between each element of the data.

More specifically, the branch of science that is worth considering the Harmony of a system or that it uses "the level of harmony" which represents "the beauty" as the keyword of the research, which are called in different terms such as "level of balance", "equilibrium level", "stability level", "level of parity", "equipoise level", "level of competition", "level of justice", "fairness level", "level of correlation", "level of performance", "Level of quality", "level of certainty", "level of health", "level of similarity", "confidence level", "level of consistency", "level of equity", "level of equality", and others. And, in the science which prefer to use the negative terms, then the spirit of the Harmony will corresponds to the terms of "the level of imbalance", "entropy", "the level of concentration", "the level of injustice", "unfairness level”, "complement level", "counterbalance level", "level of uncertainty", "level of relativity", "level of inequality", "level of inequity", and others.

The method in this article will help experts in each field of science to correct their respective theories, because, only this method is able to accurately represent the original nature of a measurement data. Otherwise, all experts will make a wrong research conclusion and inaccurate theory, if they hold to an inaccurate interpretation of the nature of the measurement data in the system being observed. 


\section{Method}

The principle of Harmony in Gradation states that the original nature of a system can only be represented by a formula that simultaneously measure the "good side" or the "harmony" and the "bad side" or the "gradations" of the elements in the system.

A formula that fulfills the requirements of the principle of Harmony in Gradation is should have two parts at once, the first is a formula that measures the "good side" or we call as the "harmony" in the system without regard to the level of disharmony, and the second part is a formula that measures the "bad side" or we call as the "gradation" in the system without regard to its harmony. Then, take a look an example formula (please note that this formula is not the only one) that meets the principle of Harmony in Gradation as follows [1], [2], [3], [4], [5], [6], [7], [8] :

$$
\text { Harmony in Gradation Index }=\frac{1}{N\left\{\sum_{i=1}^{N} S_{i}^{2}+\sum_{i=1}^{N} \sum_{j=1}^{N}\left(S_{i}-S_{j}\right)^{2}\right\}} ; i>j
$$

The formula for calculating the harmony index in equation 1 is only used in a measurement data of a system where all elements have a real positive value, where $S_{i}$ is the elemental strength, whose magnitude is equal to the ratio between the value of an element and the total value of all elements. Thus, the sum of the element strengths of all elements in the system is equal to one, and the maximum value of harmony in gradation index is equal to one, which occurs in a system if all elements in the system have the same value.

Furthermore, the formula in equation 1 is stated as meeting the principle of Harmony in Gradation, because it has both the $\sum_{i=1}^{N} S_{i}^{2}$ part (which we call as the Harmony) and the $\sum_{i=1}^{N} \sum_{j=1}^{N}\left(S_{i}-S_{j}\right)^{2}$ part (which we call as the Gradation). Where, the Harmony is representing the level of harmony of the elements in the system without is taken into account the level of disharmony between the elements, and the mathematical evidence that can be learned to in reference [9] and [10], wherein the harmony used in those references is called as "the Competition". On the contrary, the Gradation is representing the level of disharmony of the elements in the system without taking into account the level of its harmony, where the mathematical evidence can be seen in reference [11] and [12], wherein the gradation used in those references is called as "the Inequality".

Furthermore, the proof that the formula in equation 1 is one example of a formula that can 
interpret the original nature of a measurement data on a system is to use a simple logic. That is: if A complies $\mathrm{X}$ but does not meet $\mathrm{Y}$, and $\mathrm{B}$ complies $\mathrm{Y}$ but does not meet $\mathrm{X}$, then there is an opportunity to combine A and B in such a way as to meet $\mathrm{X}$ and $\mathrm{Y}$ at once. Then, in the case in equation 1, the formula that fulfill this statement (meets $\mathrm{X}$ and $\mathrm{Y}$ at once) is a formula that combines $\mathrm{C}=(1 / \mathrm{A})$ and $\mathrm{D}=(1 / \mathrm{B})$.

Moreover, when we are analyzing a system that we believe that there is should be a harmony, but the result of calculation using the formula in equation 1 had produced a low index, then we must take certain steps before starting to interpret our data, among others are by way of:

I. Dividing the system into several sub-systems such that there is a good level of harmony between sub-systems. Where, the Harmony in Gradation formula measures on a new system which are the combinations of sub-systems that have been done using simple mathematical functions (division or difference) or using complex mathematical functions depending on the level of complexity of the system being observed.

II. Combining several elements that have relatively small strength so that the system population will be less but there will be a balance of power between the existing elements that have high power and the new elements which are a combination of existing small elements.

III. Let the population not change but shift or give a portion of the strength of the elements that are relatively large to the small strength elements.

IV. The fourth way is similar to the first way, but the improvement of the harmony of a system is done by creating a new system which is a combination of the system being observed with another system, if any, that has the similar elemental distribution to the system being observed.

V. And the other ways.

\section{Result}

The simulation results as follows:

Only formulas that meet the principle of Harmony in Gradation are able to interpret the original nature of a system accurately. Exactly, the index produced by the unit of percent is representing 
the percentage of perfection of the harmony level. In other word, the systems which have the harmony level of index $\%$ of perfect will get the harmony in gradation index as index $\%$. There is no formula that can interpret the original nature of a system as can be done by a formula that meets the principles of Harmony in Gradation.

Simply put, take a look the comparison between the interpretations of nature of several systems that have different nature as presented in Figure 1. Thus, the weakness of the harmony-only formula is that it can only correctly interpret the original nature of the data when the resulting index is the biggest, but erroneously interpret the nature of systems that have almost similar nature even though they are significantly different. On the other hand, the weakness of the Gradation-only formula is that it can only correctly interpret the original nature of the data when the resulting index is the smallest but would misinterpret the nature of the some systems as a system that has the same nature when in fact the natures have a slight difference. In detail, the misinterpretation of the Harmony-only formula will occur if the level of disharmony of the system elements is significant so it can no longer be ignored anymore. Conversely, the misinterpretation of the Gradation-only formula will occur if the harmony level of the system elements is significant so that it can no longer be ignored anymore.

\begin{tabular}{|l|l|l|l|l|}
\cline { 2 - 5 } & $\begin{array}{l}\text { Original Nature of } \\
\text { Measurement Data } \\
\text { of a System }\end{array}$ & $\begin{array}{l}\text { Data interpretation } \\
\text { by Harmony in } \\
\text { Gradation Formula }\end{array}$ & $\begin{array}{l}\text { Data interpretation } \\
\text { by Harmony-Only } \\
\text { Formula }\end{array}$ & $\begin{array}{l}\text { Data interpretation } \\
\text { by Gradation-Only } \\
\text { Formula }\end{array}$ \\
\hline $\begin{array}{l}\text { system } 1 \text { has the maximum index } \\
\text { system } 2 \text { has a lowerr index than system } 1 \\
\text { system } 3 \text { has a lower index than system 2 } \\
\text { system } 4 \text { has a lower index than system } 3 \\
\text { system } 5 \text { has a minimum index }\end{array}$ & & & & \\
\hline
\end{tabular}

Figure 1 Only Harmony in Gradation Can Interpret the Original Nature of Data

\section{Discussion}

Since the formula in equation 1 is only used if all elements in the system have positive real values as they do in the "information entropy" calculation [13] and [14]. However, because the original formula have the units of bits, then certain manipulations are needed to perfect it so that it meets the principle of Harmony in Gradation. In detail, equation 2 should be considered to replace the formula in reference book [13] and [14], where the term "information entropy" is identical to the term "disharmony" in this paper. However, because the soul of the method in this 
article is to measure the harmony level instead of disharmony, then here we use the term "channel cavity" as the inverse of "entropy". Finally, in equation 3 we write a formula to

calculate the level of disharmony, or which currently uses the term "information entropy", with the note: if we want to get the maximum entropy values that are the same as the existing formula, then the calculation results in equations 2 and 3 must be divided by 2 .

$$
\begin{array}{r}
\text { Harmony Index in bit }=\log _{2}\left[N *\left\{\sum_{i=1}^{N} S_{i}^{2}+\sum_{i=1}^{N} \sum_{j=1}^{N}\left(S_{i}-S_{j}\right)^{2}\right\}\right] \\
\text { Disharmony Index in bit }=2 \log _{2} N-\log _{2}\left[N *\left\{\sum_{i=1}^{N} S_{i}^{2}+\sum_{i=1}^{N} \sum_{j=1}^{N}\left(S_{i}-S_{j}\right)^{2}\right\}\right]
\end{array}
$$

Where, pi is the probability of the symbol occurrence.

\section{Further Study of the Harmony in Gradation Principle}

Further developments of the Harmony in Gradation principle are the formulation of other formulas that meet the principles of Harmony in Gradation other than those in equation 1 and 2, including those in the formula containing the parameters of physics and biology.

\section{Online Method}

We have made several "internet calculators" that can be used online related to the calculation of harmony in gradation levels, especially those in existing conditions which have been translated into scientific terms in their respective fields of science into "competition level", "equality level (instead of inequality) "," inverse of entropy" (instead of entropy), and others.

We have made several online calculators that can be used by practitioners, researchers, and theorists. Here are the lists.

1) Calculation the Competition Level in the Industry [15], [16], [17], [18], [19], [20] at : https://www.haryadi.org/competition-level-in-the-industry/

2) Equality Correlation Calculation [21], [22], [23], [24] at: https://www.haryadi.org/equality-correlation/

3) Calculation the Income Equality [25], [26], [27] at: https://www.haryadi.org/income-equality/

4) Calculation the Inequality of Human Development Index [28], [29], [30] at: 
https://www.haryadi.org/inequality-of-human-development-index/

5) Calculation the Internet Service Equity [31], [32], [33] at: https://www.haryadi.org/internet-service-equity/

6) Calculation the Linear Regression without Intercept [34], [35], [36], [37], [38] at: https://www.haryadi.org/linear-regression-without-intercept/

7) Calculation the Modified Information Entropy [39], [40], [41] at: https://www.haryadi.org/channel-cavity/

8) Physics Equilibrium Index Calculation [42], [43], [44], [45], [46], [47] at: https://www.haryadi.org/a-new-equilibrium-index/

9) Calculation the Competition Levels among Students 48], [49], [50] at: https://www.haryadi.org/competition-levels-among-students-in-class/

10) Calculation the Consistency Score [51], [52], [53] at: https://www.haryadi.org/consistency-test/

11) Calculation the Fairness over Inequality [54], [55], [56], [57], [58], [59], [60], [61], [62] at: https://www.haryadi.org/fairness-over-inequality/

\section{Closing}

The proposed method is not intended to judge the theories of various sciences, but rather is presented here in the hope that experts will be able to evaluate their theories, and refine it if deemed necessary.

\section{Acknowledgment}

This preprint and all other preprints, papers, books, computer software coding, working papers and journals that we write related to Harmony in Gradation are the result of independent work without the help of others and without the support of research funding at all. 


\section{Reference}

[1] Sigit Haryadi. (2017). Haryadi Index and Its Applications in Science of Law, Sociology, Economics, Statistics, and Telecommunications. Penerbit Elex Media Komputindo. Jakarta. ISBN: 978-602-02-9895-5.

[2] Haryadi, S. (2018, December 20). Hundreds of Years We Live With Mathematical Formulas That Are Only "Half -Correct". Retrieved from osf.io/preprints/inarxiv/a7ws9

[3] Haryadi, S. (2018, December 6). The Fundamental of Harmony in Gradation, the Formula for Everything. Retrieved from osf.io/preprints/inarxiv/z2rvj

[4] Sigit Haryadi. (2017). Indeks Haryadi dan Penerapan di Ilmu Hukum, Sosiologi, Ekonomi, Statistik, dan Telekomunikasi. Penerbit Elex Media Komputindo, Jakarta. ISBN: 978-602-02-9896-2

[5] Sigit Haryadi. (2016). Haryadi Index for Competition, Equality and Correlation Evaluation. Penerbit Lantip Safari Media, Bandung, Indonesia. ISBN: 978-602-73231-3-2

[6] Sigit Haryadi. (2016). Haryadi Index untuk Evaluasi Kompetisi, Kesetaraan dan Korelasi. Penerbit Lantip Safari Media, Bandung, Indonesia. ISBN: 978-602-73231-3-1

[7] Dyah Rakhma Ariyanti; Sigit Haryadi. (October 2017). Analysis of Harmony In Gradation Index on 5G Cellular Network Quantitative Analysis. The 11th International Conference on Telecommunication Systems, Services, and Applications, At Lombok, Indonesia.

[8] Sigit Haryadi; Dyah Rakhma Ariyanti. (October 2017). The Fairness of Resource Allocation and Its Impact on 5G Ultra-Dense Cellular Network Performance. The 11th International Conference on Telecommunication Systems, Services, and Applications, At Lombok, Indonesia.

[9] Orris Herfindahl (1950). "Concentration in the steel industry”. Dissertation: Columbia University. Retrieved 2015-04-06.

[10] Albert Hirschman (1980-01-01). "National Power and the Structure of Foreign Trade". University of California Press. ISBN 978-0-520-04082-3.

[11] Corrado Gini. "Concentration and dependency ratios" (in Italian). 1909. English translation in Rivista di Politica Economica. 87:1997. pp. 769-789

[12] Corrado Gini. "Measurement of Inequality of Incomes". The Economic Journal. Blackwell Publishing. 31 (121):1921. pp. 124-126.

[13] Shannon, C.E., "A Mathematical Theory of Communication", Bell System Technical Journal, 27, pp. 379-423 \& 623-656, July \& October, 1948. PDF.

[14] R.V.L. Hartley, "Transmission of Information", Bell System Technical Journal, July 1928

[15] Haryadi, S. (2018, February 1). Kalkulator Untuk Mengukur Tingkat Kompetisi di suatu Industri, dengan menggunakan rumus Indeks Haryadi. Retrieved from osf.io/fy7zu

[16] Nie Levin Kusuma Adiatma ; Sigit Haryadi. (2017, October). Comparison of the Haryadi Index with Existing Method in Competition, Equality, Fairness, and Correlation Level Calculation Case Study: Telecommunication Industry. The 11th International Conference on Telecommunication Systems, Services, and Applications, At Lombok, Indonesia.

[17] Sigit Haryadi. (2017). Calculation of the Mobile Communication Competition using Haryadi Index. DOI: 10.13140/RG.2.2.15634.25280

[18] Sigit Haryadi. (2017, December). Calculator for Measurement the Competition Index \& Level. Researchgate. DOI: 10.13140/RG.2.2.23626.26568

[19] Haryadi, S., \& Riani, W. (2018, March 12). Telecommunication Competition and Interconnection. Retrieved from osf.io/preprints/inarxiv/7tfqd

[20] Sigit Haryadi. "Competition Level in the Industry." Harmony in Gradation: The Formula for Everything, 17th December 2018, https://www.haryadi.org/competition-level-in-the-industry/

[21] Haryadi, S. (2018, February 22). Equality Correlation Calculation. Researchgate. DOI: 10.13140/RG.2.2.22068.76168

[22] Haryadi, S. (2018, February 22). Kalkulator Untuk Menghitung Korelasi Kesetaraan. Retrieved from osf.io/preprints/inarxiv/7r9jy

[23] Sigit Haryadi. (2017). the Equality Correlation Method. Researchgate. DOI: 10.13140/RG.2.2.10443.80169.

[24] Sigit Haryadi. "Equality Correlation." Harmony in Gradation: The Formula for Everything, 17th December 2018, https://www.haryadi.org/equality-correlation/

[25] Sigit Haryadi. (2017, January). Calculation of the Income Equality Levels between Regions using the Haryadi Index. Researchgate. DOI: 10.13140/RG.2.2.36605.77282 
[26] Westi Riani; Sigit Haryadi. (2016). Keterbatasan Indeks Gini sebagai Ukuran Ketimpangan Pendapatan dan Solusi Metoda Alternatif. Prosiding SNaPP: Sosial, Ekonomi, dan Humaniora. Tersedia di http://proceeding.unisba.ac.id/index.php/sosial/article/view/383

[27] Sigit Haryadi. "Income Equality." Harmony in Gradation: The Formula for Everything, 17th December 2018, https://www.haryadi.org/income-equality/

[28] Haryadi, S., \& Riani, W. (2018, March 19). Pengukuran Ketimpangan Indeks Pembangunan Manusia. Retrieved from osf.io/preprints/inarxiv/x9vjt

[29] Haryadi, S., \& Riani, W. (2018, March 19). Measurement of the Human Development Index Inequality. Retrieved from osf.io/preprints/inarxiv/5r42m

[30] Sigit Haryadi. "Inequality of Human Development Index." Harmony in Gradation: The Formula for Everything, 17th December 2018, https://www.haryadi.org/inequality-of-human-development-index/

[31] Haryadi, S. (2018, March 6). Calculation the Equity Level of an Internet Service. Retrieved from osf.io/uzcmq

[32] Haryadi, S. (2018, March 6). Perhitungan Tingkat Pemerataan Layanan Internet. Retrieved from osf.io/preprints/inarxiv/rgct3

[33] Sigit Haryadi. "Internet Service Equity." Harmony in Gradation: The Formula for Everything, 17th December 2018, https://www.haryadi.org/internet-service-equity/

[34] Haryadi, S. (2017, November). Probabilitas Statistik Untuk Insinyur. Researchgate. DOI: 10.13140/RG.2.2.14304.58885

[35] Haryadi, S. (2018, February 1). KALKULATOR untuk membuat Regresi Linier Tanpa Intersep. Retrieved from osf.io/emvs7

[36] Sigit Haryadi. "Linear Regression without Intercept." Harmony in Gradation: The Formula for Everything, 17th December 2018, https://www.haryadi.org/linear-regression-without-intercept/

[37] Sigit Haryadi. (2017). The Non-Intercept Linear Regression Method. Researchgate. DOI: 10.13140/RG.2.2.18721.71522

[38] Sigit Haryadi. (2017, December). Calculator for non-intercept linear regression. Researchgate. DOI: 10.13140/RG.2.2.15761.94562.

[39] Haryadi, S. (2018, February 24). Calculation of "Channel Cavity" on Data Communications. Equality Correlation Calculation. Research gate. DOI: 10.13140/RG.2.2.30536.01288

[40] Haryadi, S. (2018, February 24). Perhitungan "Rongga Kanal" pada Komunikasi Data. Retrieved from osf.io/preprints/inarxiv/y3wcg

[41] Sigit Haryadi. "Modified Formula of Information Entropy." Harmony in Gradation: The Formula for Everything, 17th December 2018, https://www.haryadi.org/channel-cavity/

[42] Haryadi, S. (2019, January 15). The New Pythagorean Equation that Applies to all Types of Lines. Retrieved from osf.io/preprints/inarxiv/umxq3

[43] Haryadi, S. (2018, December 12). A New Postulate for Using the Harmony in Gradation to Finding the Theory of Everything. Retrieved from osf.io/preprints/inarxiv/2rak6

[44] Sigit Haryadi. "A New Pythagorean Equation that Applies to all Types of Lines." Harmony in Gradation: The Formula for Everything, 17th January 2018, https://www.haryadi.org/the-new-pythagorean-equation-that-applies-to-all-types-of-lines/

[45] Sigit Haryadi. (2017). Tantangan Untuk Menerapkan Haryadi Index pada Ilmu Fisika. Jurnal Pendidikan Fisika Sekolah Menengah. Jurnal Pendidikan Fisika Sekolah Menengah. Vol 9 no 1 2017. ISSN: 1979-4959. Available at : https://www.researchgate.net/publication/316683866

[46] Haryadi, Sigit. 2018. "Always Move to Seek Perfection: The New Equilibrium Index Calculation for the Science of Physics and Astronomy." INA-Rxiv. July 13. osf.io/preprints/inarxiv/8hrnb.

[47] Sigit Haryadi. "A New Equilibrium Index for the science of Physics and Astronomy." Harmony in Gradation: The Formula for Everything, 17th December 2018, https://www.haryadi.org/a-new-equilibrium-index/

[48] Haryadi, S. (2018, February 17). Calculation the Competition Levels between Students in Class and the Relation to the Teacher or Lecture Fairness in Teaching. Researchgate. DOI: 10.13140/RG.2.2.30359.06569

[49] Haryadi, S. (2018, February 17). Perhitungan Tingkat Kompetisi antar Murid atau Mahasiswa di Kelas dan Kaitannya Dengan Keadilan Guru atau Dosen Dalam Mengajar. Retrieved from osf.io/a894w

[50] Sigit Haryadi. "Competition Levels among Students." Harmony in Gradation: The Formula for Everything, 17th December 2018, https://www.haryadi.org/competition-levels-among-students-in-class/

[51] Haryadi, S., \& California, S. H. (2018, March 14). New Method to Calculate the Level of Consistency of the Pauli \& Kraepelin Tests. Retrieved from osf.io/preprints/inarxiv/ty326

[52] Haryadi, S., \& California, S. H. (2018, March 14). Metoda Baru Untuk Menghitung Tingkat Konsistensi pada Tes Pauli \& Kraepelin. Retrieved from osf.io/preprints/inarxiv/qht8j 
[53] Sigit Haryadi. "Consistency Test." Harmony in Gradation: The Formula for Everything, 17th December 2018, https://www.haryadi.org/consistency-test/

[54] Sigit Haryadi. (2017). The Fairness over Inequality Index: Unfairness is Disaster - a notebook of Sigit Haryadi. Researchgate. DOI: 10.13140/RG.2.2.34379.49449.

[55] Haryadi, S. (2018, February 7). Statistik Terapan: Pengujian Regulasi \& Kebijakan Telekomunikasi. Retrieved from osf.io/3pkfw

[56] Haryadi, S., \& Riani, W. (2018, March 5). METODE PENETAPAN TARIF PAJAK PENGHASILAN YANG BERKEADILAN. Retrieved from osf.io/preprints/inarxiv/ayg58

[57] Sigit Haryadi. (2018, February). Applied Statistics for Assessment of the Regulation and Policy: case study in Telecommunication Industry. DOI: 10.13140/RG.2.2.15774.02884

[58] Westi Riani; Sigit Haryadi. (2017). CALCULATOR for the Government to make the Fair Policy of Tax Rates. Researchgate. DOI: 10.13140/RG.2.2.18550.50246. Available online at http://sigitharyadi.net/multidicipline/income-tax-rates-calculator-id/

[59] Westi Riani; Sigit Haryadi. (2017). The Method Of Tax Rate Determination Based On Fairness. Prosiding Seminar Nasional SNaPP2017, Bandung, Indonesia.

[60] Westi Riani; Sigit Haryadi. (2017). Prosiding SNaPP2017 "THE METHOD OF TAX RATE DETERMINATION BASED ON FAIRNESS". Conference: Seminar Nasional Penelitian dan PKM (SNaPP) 2017At: Bandung, Indonesia.

[61] Sigit Haryadi. "Fair Policy of Tax Rate." Harmony in Gradation: The Formula for Everything, 17th December 2018, https://www.haryadi.org/fair-policy-of-tax-rates/

[62] Sigit Haryadi. "Fairness over Inequality." Harmony in Gradation: The Formula for Everything, 17th December 2018, https://www.haryadi.org/fairness-over-inequality/ 